\title{
Management of classical Islamic education
}

\author{
Leni Martha Karisma *, Joko Sutarto, Tri Suminar \\ Department of Nonformal Education, Postgraduate, Universitas Negeri Semarang. \\ Kampus Sekaran, Gunungpati, Semarang 50229, Indonesia. \\ * Corresponding Author. Email: martha_leni@ymail.com \\ Received: 3o September 2019; Revised: 18 October 2019; Accepted: 10 December 2019
}

\begin{abstract}
The purpose of this research is to describe the planning, organizing, implementing, and evaluating of classical Islamic education at Kuttab Al Fatih Semarang. This research uses a qualitative approach. Data collection with observation methods, documentation studies and six interviews. Validity of data with extended entry techniques, observational diligence techniques, and triangulation techniques. The results showed the management of classical Islamic education in Kuttab Al Fatih Semarang ranging from planning, organizing, implementation, and evaluation done in accordance with the concept of Islam in the heyday of Islam that aspire to build Quality generation. The management like planning, organizing, implementing, evaluating of the classical Islamic education in Kuttab Al Fatih is very effective to create a students who want to have a character of faith, to be the memorization of the Qur'an, deepen the miracle of the Qur'an, mastering the language of civilization and have the skills of life.
\end{abstract}

Keywords: character education, social model problem solving, SD Muhammadiyah Tanjung 11, Jakarta

How to Cite: Karisma, L., Sutarto, J., \& Suminar, T. (2019). Management of classical Islamic education.JPPM (Jurnal Pendidikan dan Pemberdayaan Masyarakat), 6(2), 140-145. doi:https://doi.org/10.21831/jppm.v6i2.27397

doi https://doi.org/10.21831/jppm.v6i2.27397

\section{INTRODUCTION}

Kuttab Al Fatih is an elementary school institution intended for children aged 5-12 years which was built since June 2012 with a curriculum that focuses on faith and the Qur'an. This curriculum has been formulated in routine discussions since 6 years ago and was used as a source for arranging guide modules in learning. This institution digs its curriculum from the books of the scholars based on the Qur'an and Sunnah (Ashari \& Sembodo, 2012).

Kuttab Al Fatih's vision is to create a bright generation at young age, while its mission is to teach and invest the character of faith; memorize the Qur'an; explore, research, and prove the miracle of the Qur'an; speak civilization; have life skills (Ashari \& Sembodo, 2012).

The objective of the management of education is to realize the vision and mission that have been planned (Novianti, 2015). The educational principles applied in Kuttab Al
Fatih are in accordance with the objectives of classical Islamic education. That contextualization of kuttab in Arab in the past, as well as recording the changes in the kuttab education system from the era of the Prophet to the era of Khulafaur Rashidin.

Supiani et al. (2016) states that the plans prepared by teachers are in accordance with the curriculum set in the school. However, there are still some teachers who have not been able to plan effectively in the learning. The learning implementation applied in Kuttab Al Fatih teachers motivate students by using various methods and learning media from the initial activities starting with reading and muraja'ah and talaqqi memorizing the chapters individually, and in the final activities, the teachers provide motivation for students to repeat their memorization.

Andi (2013) reveals that Islamic Education in Indonesia has undergone changes and development in the political map of national education. Changes and development of 
JPPM (Jurnal Pendidikan dan Pemberdayaan Masyarakat), 6 (2), 2019 - 141

Leni Martha Karisma, Joko Sutarto, Tri Suminar

Islamic education is influenced by the interests of political ideology and other interests in the state of policy making.

Meria (2012) states that the vision and mission of Islamic education is rahmatan lil 'alamin, which enables Islamic education to be a guideline to direct humans to become leaders in the world. The objective of the government decision about the national education system in 2003 is to filter the negative impact of globalization so that the students will not lose their national identity. To overcome this condition, teachers and educators must be a good model for students and must strengthen their Islamic characters.

Anjani (2018) the implementation of a faith curriculum that aims to form a bright generation at an early age is in accordance with the vision and mission of the school. The curriculum implemented designed by the school is adjusted to the vision, mission and objectives of the school. The differences from the study that the author will conduct is the management of classical Islam developed at Kuttab Al Fatih Semarang.

Altbach (2002) reveals that management of education based on the life of the Prophet Muhammad, which is applied by leading schools, can lead these schools to become strong Islamic educational institutions.

Breen (2018) states that management education implemented in Finland is the best education in the world. This deals with the planning, implementation, and policies of the Finland government.

\section{METHODS}

This research is qualitative research. It is a research procedure that produces descriptive data in the form of written or spoken from the participants observed. This research is descriptive research which is a research used to describe or explain existing phenomena, both natural phenomena and human engineering.

The subject of this research was the person in charge in Kuttab Al Fatih Semarang, while the object was the management of classical Islamic education in Kuttab Al Fatih Semarang which includes planning, organizing, implementing and evaluating.
Data collection techniques used in this research were interviews with person in charge Kuttab, Kuttab teacher, parents of students, documentation study, and observation in Kuttab Al Fatih Semarang.

Data analysis techniques used in this study were data collection, data reduction, data presentation, and conclusions or verification. The data validity technique used were extending participation, perseverance of observation, and triangulation.

\section{RESULTS AND DISCUSSION}

Kuttab Al-Fatih Semarang makes effort to realize the kuttab in the glory era of Islam to be raised again right now. Kuttab education model at that time had a lot of diversity. This is inseparable from the needs and perspective of its founder. The current development also demands a change. Likewise, the kuttab continues to develop according to the needs of the era and the location it is built. So, the existence of Kuttab Al-Fatih Semarang is not entirely the same as the kuttab in classical era.

The Islamic institution of Kuttab $\mathrm{Al}$ Fatih is a level alternative education with a different elementary school from the educational institution that has developed in Indonesia before. Kuttab Al Fatih did not use the government curriculum but rather composed its own curriculum by referring to the management of classical Islamic education.

\section{Planning}

At the beginning of its development, kuttab had only objective to teach children to read and write. When Islam began to spread, kuttab was not only used as a place to learn reading and writing, but also to teach the basics of religion and the Qur'an. The products produced by kuttab were only students who can read and write.

The results are in line with Apriani and Suminar (2015) which states that the education orientation of leading school which at first only provided experience in the form of skills training, then Islam add it with religious orientation, character, and also other useful sciences. 
JPPM (Jurnal Pendidikan dan Pemberdayaan Masyarakat), 6 (2), 2019 - 142

Leni Martha Karisma, Joko Sutarto, Tri Suminar

The results are in line with Setiobudi (2017) stating that education from the AlFatih kuttab was inspired by the success of the kuttab during the Islamic era that was able to produce alumni who had sufficient religious and scientific knowledge so they can become great figures at young age. From there, the general goal of the Kuttab Al-Fatih is creat a bright generation at a young age.

The specific objectives to be achieved include realizing students who have the character of faith, producing memorizers of the Qur'an, exploring the miracles of the Qur'an, mastering the language of civilization and having life skills so that later, it can create cageneration of drafter, executor, and leader in preparation to become the best generation that has been foreseen. The objectives are almost similar to the 6 educational objectives according to Ibnu Khaldun to prepare someone in terms of religion, morals, social, works or skills, and thoughts. However, the objective to prepare children in terms of art is not included in Kuttab Al-Fatih.

\section{Organizing}

Organizing here is defined as the process of arranging organizational structure in accordance with the objectives, resources, and environment (Siagian, 2005). The organizational structure of teachers and employees in Al Fatih Kuttab Semarang consists of Branch Guidance in charge of being responsible for the Semarang Kuttab branch. The person in charge in this branch is entrusted to Ustadz Adityawarman, S.E. M. Acc, Akt.

Besides the person in charge of the branch, there is also a Syar'i board whose duty is to be in charge of the syar'i laws in Kuttab.It is entrusted to Ustadz Taufiq El Hakim, Lc.

Head of Al Fatih Kuttab in Semarang is entrusted to Ustadz Syah Azis Parangin Angin, S. Th I, M.Sc. Underneath, there are several coordinators including the coordinator of the Qur'an which is entrusted to Ustadz Nur Khasan and inside it, there are 23 teachers of the Qur'an. Coordinator of Sports curriculum is entrusted to Ustadz Iltizam Bima Amarullah, S.Pd. which consists of 4 Sports teachers. While, the coordinator of Faith curriculum which consist of 24 Faith teachers is assigned to Ustadz Nur Rokhim.
There are also number of educational staff including administration and finance, social and public realtion, PKBM licensing, and cleanliness.

The distribution of the mandates is in accordance with the field and expertise of the teacher council in Kuttab Al Fatih Semarang. The results are in line with (Setiobudi, 2017) stating that organizing is a step to determine, classify, and manage various activities.

\section{Implementing}

The learning implementation in Kuttab Ar-Fatih is not much different from the approach of classical kuttab. Exemplary is something that must be practiced by the kuttab teachers. This is because the objects being taught are children who easily imitate adult behavior. The teachers become a model whose behaviors are observed and then imitated by the students. So, it is a must for the teachers to maintain their attitude and authority as they are teaching. The other approach is the habituation approach. With habituation, new habits will emerge from repeated practice according to the research from Slamet et al. (2017). One of the ways in which Kuttab A1-Fatih is practiced is by pledging every morning. Pledges here are intended to strengthen and remind the objectives of their learning and its manners. Besides pledging, they are also accustomed to praying in congregation at the mosque, especially at the level of Kuttab Awwal 3, for those who are almost at the age of baligh.

Classical kuttab learning is usually carried out in the corner of a mosque or at Ms. (Raharjo \& Suminar, 2011). However, in Kuttab Al-Fatih which has its own building, the teachers try to add something new through the experience approach with outing class. Students were invited to visit certain places at the beginning of the opening theme of learning to be more able to give a concrete picture before starting to learn concepts. Outing class provided basic skills and expertise as a means of developing children's creativity. In this way, teachers can train and see how the affective development of children. The learning outcomes obtained will usually last longer since it was memorable and meaningful (Smith \& Willower, 1973). 
JPPM (Jurnal Pendidikan dan Pemberdayaan Masyarakat), 6 (2), 2019 - 143

Leni Martha Karisma, Joko Sutarto, Tri Suminar

Related to the method used in Kuttab Al-Fatih, the method used in the curriculum of faith is different from the curriculum of the Qur'an. In the Qur'an curriculum, the method used is talaqqi, tasmi, and drill with a small halaqoh or halaqoh jama'i model when tasmi is done at the same time together.

This face to face method is used when students learn to read the Qur'an with the teacher. The students were taught the letter spoken by the teachers. Then, the tasmi method or listening is used when when students deliver memorization or murojaah. The teachers listened to the memorization of students and then justified it if there were mistakes or reminded him/her if there are parts of the verse that missed. Platonova et al. (2015) the results are in line with which states that the drill method is implemented to train students to learn writing hijaiyah letters. These writing skills were taught in accordance with the level of difficulty at each level.

Learning applied in the Faith curriculum was the classical model. The students sat on the floor with his hands neatly on the table, while the teacher sat in a chair explaining the lesson. The learning method used in the Faith curriculum was similar to learning in general which uses lecture, question and answer, stories, parables, and others. The methods used was flexible in accordance with the materials being taught. The materials taught were in accordance with the theme of the Kuttab Activity Plan.

Kuttab teachers were also encouraged to use teaching aids when delivering the materials. However, the use of instructional media in the form of electronic devices should to be minimized. The concern is, if teachers later get accustumed to electronic devices, they will experience difficulties if there is no access to electricity. For the students as well, they must be taught not to depend on electronic devices. The available learning facilities are not very complete. This is indeed the regulation of the Kuttab which says that the students of the Kuttab are taught to be able to keep studying even with minimal conditions and facilities.

The use of methods and media was discussed beforehand in the preparation meeting of the Kuttab Activity Plan. Not only the methods and media, but also the insertion of the story delivered to the students must be in accordance with the requirements of the Syar'i board. After the method and teaching aids were applied, they were then reported to be evaluated together.

\section{Evaluating}

The evaluation system in Kuttab A1Fatih is much more modern and developed compared to the classical kuttab. The evaluation applied can be adjusted to the conditions of the era that require recording of the development process and learning outcomes in the presence of report cards according to Sandi et al. (2018). The use of report cards in Kuttab A1-Fatih is only as a report on students' learning progress towards their parents without ranking order and also the conclusion of students' intelligence levels. This is in line with the flow of humanistic learning theory or authentic/ real assessment. It is expected to create social stratification, conflict, and no competition. Taking report cards in Kuttab Al-Fatih requires both parents to be present together to listen to their children report progress.

Kuttab teachers only give grades based on the conditions that have been set. Writing report cards is explained by numbers (numerical) and also by sentences (descriptive) so that parents can conclude themselves related to the limits of their children's ability. It is the parents who have to work harder to educate their children at home through the BBO program.

The orientation of the main assessment is on their morals and manners (affective) rather than on the knowledge aspect (cognitive) and skill (motor) aspects. This emphasis on morals and etiquette aspects is considered more important, as the scholars used to learn the morals from their teachers before learning their knowledge. Someone who has intelligence, extensive knowledge, and good skills ability will not get more attention from the community when he/she has no good character and manners.

The evaluation methods used were testbased and some were non-test according to Raharjo et al. (2016). Non-test evaluations included evaluating attitudes from daily 


\section{JPPM (Jurnal Pendidikan dan Pemberdayaan Masyarakat), 6 (2), 2019 - 144 \\ Leni Martha Karisma, Joko Sutarto, Tri Suminar}

activities, daily assignments and attendance and mutabaah or the progress of students' memorizing. While the test-based evaluation, it can be a written or spoken test by memorizing when the theme exam conducted, or the test for the next juz or the final semester exam.

The type of evaluation used in Kuttab Al-Fatih consists of formative and summative evaluation. The formative evaluation for the Faith curriculum was done for each theme test, while for the Qur'an curriculum was done in the form of a next juz test. Summative tests were conducted at the end of each semester to find out the final results of the student learning progress during one semester.

\section{CONCLUSION}

Based on the results of Classical Islamic Education Management in Kuttab A1-Fatih Semarang, it can be concluded as follows: The kuttab education system model in Kuttab A1Fatih Semarang has several components including: planning, organizing, implementing and evaluating.

Kuttab Al-Fatih's objective is to produce a bright generation at young age. Specific objectives to be achieved are to create students who have the character of faith, to create memorizers of the Qur'an, to explore the miracles of the Qur'an, to master the language of civilization and to make students who have life skills. Whereas, the ultimate goal to be achieved is the realization of the best generation who will welcome the Khilafah 'a la Minhajin Nubuwah.

The organization of teachers and employees in Al Fatih Kuttab Semarang consists of Branch Guards in charge of Kuttab in Semarang, person in charge in who is in charge of Islamic laws in Kuttab, head of Kuttab, under which there are several coordinators coordinators including the coordinator of the Qur'an, Coordinator of sport curriculum, Faith coordinator, and there are number of educational staff including Administration and finance, social and public relation, PKBM licensing, and cleanliness.

The implementation used are modeling, habituation, and experience approaches through class outing. The model used for the Al-Quran curriculum is Association and the curriculum which applies classical. The method used in learning Faith are in the form of talaqqi, memorizing tasmi dril for the Qur'an and lectures, questions and answers, stories, guides, etc.

Evaluations used are tests and nontests. Formative tests include per-theme and next juz exam, while Sumative tests are in the form of final semester exams. Non-test evaluation is taken from daily reflection, attendance, daily tasks and mutabaah memorization.

Kuttab Al-Fatih Semarang emphasizes character education through the Curriculum of Faith and the Qur'an. It also applies thematic learning which presents several kinds of content in one particular theme.

\section{REFERENCES}

Altbach, P. G. (2002). Research and training in higher education: The state of the art. Higher Education in Europe, 27(1-2), 153-168.

https://doi.org/10.108o/0379772022000 003297

Andi, H. (2013). Politik pendidikan Islam dalam konfigurasi sistem pendidikan di Indonesia. HUNAFA: Jurnal Studia Islamika, $\quad 10(1), \quad 177$. https://doi.org/10.24239/jsi.v10i1.24.177 $-202$

Anjani, R. P. (2018). The Implementation of faith curriculum in Kuttab Al Fatih North Purwokerto Banyumas Regency. IAIN Purwokerto.

Apriani, F., \& Suminar, T. (2015). Manajemen penyelenggaraan program bina keluarga remaja melalui kegiatan keterampilan merajut di RW o6 Kelurahan Bandarharjo Ungaran Barat. Journal of Nonformal Education and Community Empowerment, 4(1), 1-6. https://journal.unnes.ac.id/sju/index.p $\mathrm{hp} /$ jnfc/article/view/8021

Ashari, B., \& Sembodo, M. I. (2012). Modul Kuttab 1. Yayasan Al Fatih.

Breen, D. (2018). Muslim schools, communities and critical race theory. In Muslim Schools, Communities and Critical Race Theory: Faith Schooling in 
JPPM (Jurnal Pendidikan dan Pemberdayaan Masyarakat), 6 (2), 2019 - 145

Leni Martha Karisma, Joko Sutarto, Tri Suminar

an Islamophobic Britain? (Vol. oo, Issue oo). Palgrave Macmillan UK. https://doi.org/10.1057/978-1-13744397-7

Meria, A. (2012). Pendidikan Islam di era globalisasi dalam membangun karakter bangsa. Al-Ta Lim, 19(1), 87. https://doi.org/10.15548/jt.v19i1.10

Novianti, I. (2015). Reorientasi model pendidddikan Islam klasik di Indonesia (Studi terhadap Kuttab Al Fatih) (Vol. 13). Lembaga Penelitian dan Pengabdian Masyarakat IAIN Purwokerto.

Platonova, E., Bogomolova, J., Musarskiy, M., \& Igumnov, O. (2015). Various approaches to financing Russian higher education institutions integrating into the global educational environment. Procedia - Social and Behavioral Sciences, 214(June), 393-398. https://doi.org/10.1016/j.sbspro.2015.11. 682

Raharjo, T. J., \& Suminar, T. (2011). Penerapan pedagogi dan andragogi pada pembelajaran pendidikan kesetaraan kelompok belajar paket $\mathrm{A}, \mathrm{B}$, dan $\mathrm{C}$ di Kota Semarang. Edukasi, 1(1). https://journal.unnes.ac.id/nju/index. php/edukasi/article/view/954

Raharjo, T. J., Suminar, T., \& Muarifuddin, M. (2016). Peran pusat kegiatan belajar masyarakat dalam menanggulangi kemiskinan melalui pendidikan nonformal di Jawa Tengah. Journal of Nonformal Education, 2(1). https://doi.org/10.15294/jne.v2i1.5310

Sandi, P. A., Sutarto, J., \& Yusuf, A. (2018). Homeschooling model management (A study at Anugrah Bangsa package A Homeschooling Semarang). Journal of Primary Education, 7(2), 204-210. https://doi.org/10.15294/JPE.V7I2.2360 8

Setiobudi, E. (2017). The effort of education management in conducting deradicalization of boarding school (Study in the village of Tenggulun Subdistrict Solokuro Lamongan East Java Province). Journal of Education and Practice, $\quad 8(8), \quad 160-165$. https://iiste.org/Journals/index.php/JE $\mathrm{P} /$ article/view/36046

Siagian, S. P. (2005). Filsafat administrasi. Haji Masagung.

Slamet, S., Sudana, I. M., \& Suminar, T. (2017). Manajemen pembelajaran berbasis Kurikulum 2013 di SMP Islam Kota Semarang (Studi empiris di SMP Sub Rayon o2 Kota Semarang). Educational Management, $\quad 6(2), \quad$ 115-122. https://journal.unnes.ac.id/sju/index.p hp/eduman/article/view/22776

Smith, C. M., \& Willower, D. J. (1973). Administration, management, economics. The Educational Forum, 37(3), 365-366. https://doi.org/10.1080/00131727309339 235

Supiani, E., Murniati, M., \& Usman, N. (2016). Implementasi manajemen pembelajaran Al-Qur'an di Sekolah Dasar Islam Terpadu Nurul Ishlah Banda Aceh. Jurnal Administrasi Pendidikan, 4(4). http://www.jurnal.unsyiah.ac.id/JAP/a rticle/view/5680 